\title{
Change Management Study of Horticulture 2015 - Conditions and Success Factors
}

\begin{abstract}
The increasing organizational size, as a result of the industry's structural change, is leading to crises in German horticultural companies. Therefore, the present study examines the causes of fundamental change processes in horticultural companies, indicates the overriding trends and identifies the success factors of change initiatives. For this purpose, over 150 decision makers with over 10 years' experience in their respective organization were surveyed from May to December 2014. The megatrends are environmental issues, changed consumer behavior, resource shortages and the labor market. Currently, the reasons for change lie in a changing market strategy/sales approach, business succession and submission and external changes in the legal conditions. Among the most difficult problems occurring in the implementation of change processes are low willingness to take responsibility, interest and goal conflicts of the involved organization's members and a sacrifice of long-term actions for short-term profit improvements. The most important success factors of change processes include realistic, clear visions/goals and their communication, team spirit and motivation and a coordinated chronological procedure. Six factors of the psychological level of the change success are presented. The results of the study can help to recommend a design for change processes in companies within horticultural manufacturing.
\end{abstract}

Keywords: business transformation, human resources management, project management, organizational change, economical sustainability

JEL classifications: L16, L21, L22, L25, L66, M12, O13

\section{Introduction}

Despite the relevance of change management to the corporate practice in horticultural companies, only a few comparative studies on horticulture can be found in the German- 
speaking world and beyond. ${ }^{1}$ Change management is also important for small organizational units, which are common in horticulture. Even small organizations experience crises as triggers of change processes (Storck and Bokelmann, 1995). Thus, for example, company succession constitutes a significant crisis for small enterprises. Through the takeover of corporate governance, a change is triggered in the corporate culture in many cases. Behaviors that were considered desirable by a senior may not be desired by the new leadership. Therefore, the old and the new culture clash and cause friction processes.

With this study, the current situation was determined for change processes in German production horticulture. The study of the specific economic sector of horticulture was based on a series of extensive analyses undertaken by Capgemini Consulting in the years 2003 (Claßen, Alex, and Arnold, 2003), 2005 (Claßen, Arnold and Papritz, 2005) and 2008 (Claßen and von Kyaw, 2007; see: von Kyaw and Claßen, 2010 and Keicher, Anke, Bohn, Crummenerl, and Mergenthal, 2012). Several aspects were deepened and extended in comparison with the listed studies (for example, the analysis of statistical relationships). Other topics - in which no meaningful results were expected - were not considered. Some questions and response categories of the key dimensions of change management (Meyerding, 2014a and Meyerding, 2014b) were adopted to carry out a comparison of horticulture with larger organizational units in Germany. The questions were rephrased to increase their intelligibility for horticultural entrepreneurs. In particular, technical business terms, which are also often in English, were transcribed and illustrated by examples.

The focus of the present study is on:

- The understanding and attitude of horticultural entrepreneurs towards change management

- The occasions for change initiatives in horticultural companies

- The organization and framework conditions of change management in horticulture

- The success factors of change management in horticulture

\footnotetext{
${ }^{1}$ Considerations of the causes of developmental processes in horticulture can be found in Berndt (1984, pp. 54 ff.), Böckelmann (1992, pp. 106 ff.) and Bock (1994, pp. 49-57). Storck and Bokelmann (1995, pp. 303 ff.) establishes a relationship between plant growth and business development.
} 
The main objective of the study is to develop an understanding of which success factors in change initiatives in German production horticulture companies are particularly relevant.

All the topics of the study were analyzed in relation to structural parameters, like the number of employees, number of seasonal workers, perceived economic success compared with direct competitors, perceived "difficulty" encountered in the company changes and perceived pace of change (see Figure 1; Kettinger and Grover, 1995 and Walker, Armenakis, and Bernerth 2007). But structures may be defined in various ways (see Tran and Tian, 2013), the ones chosen in this study were selected because they can easily be evaluated subjectively by the decision maker in a horticultural company. It is assumed that all of these structural parameters have an impact on the issues examined in the present study (for example, the success factors). Thus, a lack of personal, financial and time resources has an (assumed) influence on the change strategy, for example on the degree of participation of those affected by the decision-making process. The fewer the resources, the less participation is possible. On the other hand the number of employees can affect the level of hierarchy in the company, which would lead to different change strategies in smaller versus larger organizations. For the horticultural industry one should distinguish between seasonal and permanent workers, as seasonal workers often perform more standardized work and do probably not need to be involved in decision-making processes. As mentioned the factors change speed and economic success mainly refer to the availability of resources for the change project. The factor subjective difficulty of change might be an indicator of how much the change impacts the organization.

(insert Figure 1 here)

The present article is structured as follows: After an introduction of the terminology change management and the conceptual approach the study is based on, the implementation of the study is presented, including the description of the sample. The results and discussion section is divided into three subsections. In the first the causes and background circumstances of change initiatives in the sample of German horticultural companies are presented and discussed. In this section the trends behind the change initiatives, the occasions of change projects in German horticulture and the main objectives 
of these initiatives are presented. The second subsection focusses on the attitudes of decision makers towards change management to evaluate the standing of change management in German horticulture. The third subsection deals with the main objective of this study, i.e. to evaluate which challenges change projects in horticulture face, their success factors and the relationships between these factors and the structural variables from figure 1 . The article closes with a summary and conclusions.

\subsection{Terminology: Change Management}

To understand the concept of change management in this study, the definitions of Gattermeyer/Al-Ani and Vahs should be used. Gattermeyer and Al-Ani define change management as follows: "Under change management all measures are subsumed that are necessary for the initiation and implementation of new strategies, structures, systems and practices" (Gattermeyer, 2001, p. 14). Vahs refers to its holistic nature by defining change management as: "Change management is the purposeful analysis, planning, implementation, evaluation and ongoing development of holistic change measures in companies" (Vahs and Leiser, 2003, p. 32). The definition by Vahs can be linked with the objective of change management according to Klaffke: "The ultimate goal of change management is to achieve the stabilization of the everlasting change" (Klaffke, 2005).

\subsection{Conceptual Approaches to the Design of the Change Management Process}

If change management is understood as an integrative approach, it considers both a factual level with the typical project phases of analysis, planning, implementation, monitoring and further development and a psychological level with the stages of unfreezing, changing and refreezing (Lewin, 1953). The two levels are different processes that have to be coordinated to avoid a "reality gap" arising (see Figure 2). After the revolutionary act of the process's start, the learning process at the psychological level leads to a change in behavior of the employees and a process of change on the objective level to an organizational change. The change result depends on the behavior and the organizational change. In practice, the operational and organizational structure changes many times faster than the behavior of employees and the corporate culture, producing a "reality gap" and thus leading to a suboptimal change result. To ensure an optimal change re- 
sult, change management needs to follow an integrated approach and coordinate the psychological and the factual level.

(insert Figure 2 here)

The two levels have to be planned and executed in parallel in a synchronous process. The starting point for the change initiative is the strategic goal definition as the input variable. The target values arising from the options of strategic change in the form of the nature of the change initiative (e.g. the strategic realignment of the company, product innovation, merging of companies) and the target dimension of change success (e.g. ensuring competitiveness, increased market share, stronger market and customer orientation). Following the strategic goal definition is the actual change process, with its stages of analysis, planning, implementation and evaluation. The change process involves both the factual and the psychological level to avoid a "reality gap." The success factors on the psychological level are shown in Figure 3.

Based on the studies by Vahs (Vahs and Leiser, 2003) and Picot (Picot, Freudenberg, and Gaßner, 1999), universal factors of change success (unpublished Script: Schnitzler, C.C.: Change Management, Fachhochschule Hannover, 2011) can be deduced for the psychological level (Meyerding, 2014a). Figure 3 shows the success factors with the associated issues in this study.

\section{(insert Figure 3 here)}

The organizational structure of the change initiative (S1) may consist of the steering committee, the core team, the individual project teams and the company as a whole, in which the former are often combined into one person in horticultural companies (Meyerding, 2014a).

In the context of leadership behavior (S2), two extremes of management orientation can be named: transactional leadership and transformational leadership. The object of transactional leadership is to offer incentives in exchange for the work that has to be performed. The motivation and commitment of employees are achieved by the design of the work environment and incentive systems. Transformational leadership is not based 
solely on an exchange relationship. The influence on the behavior of the employees is achieved by a goal and value change. Enthusiasm should be built through meaning and the charisma of the leader, which means an increase in output resulting from a specific "cultural" control (Krüger, 2012).

The success factor communication (S3) raises the question of the relationship between bottom-up and top-down communication and the way in which these communication streams should be organized. In terms of top-down communication, attention needs to be paid to the date of the communication, the communication channel, the contents of the communication, the communicator and the form of communication. Bottom-up communication is used for the disclosure of tacit knowledge and also deals with the organization of knowledge dissemination and transmission (Meyerding, 2014a).

Participation (S4) is particularly useful in dealing with knowledge holders. This is achieved through the integration of carriers of experiential knowledge into the change management process as well as the transfer of decision and action rights to knowledge holders (especially to affected employees and external consultants) (Picot, et al. 1999, p. 135). Another possibility is the movement of change management knowledge to the person responsible for change management by knowledge disclosure in the form of bottom-up communication (Meyerding, 2014a).

The functions of the success factor training (S4) are the creation and expansion of employees' skills and the resulting increase in motivation and the credibility of strategic plans. Training can consist of three different components: professional knowledge, methodological knowledge and interpersonal knowledge (Meyerding, 2014a).

The success factor incentives (S5) is used to induce preference compatibility between employee and company goals. Four different types can be distinguished: material incentives, incentives from the task itself, social incentives and incentives for organizational framework conditions (Meyerding, 2014a).

Controlling (S6), as the last success factor, has the objective of "... coordination of information-, planning-, monitoring-, organizational- and personnel management systems to ensure a targeted steering of the change initiative" (Picot, et al. 1999, p. 150), thus 
taking on a targeting function, a service function (communication of deviation between actual and desired values) and an adjustment innovation function (e.g. through benchmarking and the identification of best practices; Picot, et al. 1999, p. 150 and Meyerding, 2014a).

The limitations of the survey in the present study result from the subjective assessment by managers or horticultural entrepreneurs. Accordingly, the results of two companies are not necessarily comparable. Furthermore, the success factors could be judged differently by other groups, such as employees or external consultants. In individual cases, the specific situation of the company leads to other success factors. The most important limitation of the study is that it is the implementation of change management measures at the right time (S7) that leads to positive results. This timing can only be planned depending on the situation and therefore cannot be mapped in the study.

\section{Materials and Methods}

The study is based on a survey of executives from German production horticulture companies conducted between May and December 2014. Horticultural entrepreneurs were contacted with a personalized letter by post or email. The addresses were taken from a commercially available horticulture business directory (Haymarket Media, 2009, 2010). For this purpose, a questionnaire was created with the online tool LimeSurvey and the appropriate link was sent via the letter or email. A total of 159 fully usable questionnaires were evaluated. Complete questionnaires were considered to be ones in which the respondent had progressed through the whole questionnaire, that is, he/she must not have answered all the questions. The survey questions are based on a series of analyses undertaken by Capgemini Consulting in the years 2003 (Claßen et al., 2003), 2005 (Claßen et al., 2005) and 2008 (Claßen and von Kyaw, 2007; see: von Kyaw and Claßen, 2010 and Keicher et al., 2012). Change management and related topics are not easy to grasp for horticultural entrepreneurs, because of their education. For this reason, the questionnaire was optimized in several passes through pretests with executives and aspiring executives in horticulture. Many technical business terms had to be represented by tangible synonyms and explanations with examples. The result was a questionnaire with a total of 5 thematic areas, 34 issues and often diverse response categories. Many questions were realized due to multiple responses; to avoid a possible primacy or recen- 
cy effect, ${ }^{2}$ the order of the answer choices was randomized for each participant. In addition, there was often an opportunity to give free answers. Despite all the efforts, the participation rate could not be prevented from falling in the last questions. In addition to the individual evaluations of the sets of questions, the relationships with certain structural variables (see Figure 1) were investigated. Multiple responses produce dichotomous data; therefore, Kendall's tau-b $\left(\tau_{\mathrm{b}}\right)$ was used to calculate most correlations (see: Field, 2009, pp. 181-182). For ordinal or parametric data, Spearman's correlation coefficient $\left(r_{s}\right)$ was used as normal distributions were not present (see: Field, 2009, pp. 179_ 181). The direction of relationships is not always clear in advance; therefore, two-sided analyses were performed throughout. In the text, the relationships (correlations) are presented as follows: (1. type of correlation coefficient; 2. level of significance; 3. number of considered records in the calculation), for example $\left(\tau_{b}=.26 ; \mathrm{p}<0.01 ; \mathrm{n}=106\right)$.

\subsection{Structure of the Companies in the Sample}

As Figure 4 (left) shows, the surveyed horticultural companies come from all over Germany.

\section{(insert Figure 4 here)}

The companies analyzed represent the entire spectrum of German production horticulture (see Figure 4, middle). One-third of the respondents classified themselves into the category floriculture (33\%); vegetable firms are represented by 28\%. Tree nurseries are overrepresented, with almost a third of the respondents (31\%), whereas fruit farms, accounting for $8 \%$ of the respondents $(\mathrm{N}=169)$, are under-represented compared with the population. ${ }^{3}$ The focus is on small and medium enterprises. Thus, $75 \%$ of the companies surveyed have fewer than 10 employees (excluding seasonal workers) and only 3\% have more than 50 employees (see Figure 4, top right, $\mathrm{N}=166$ ). Of all the companies represented in the study, 62\% employ an annual average of fewer than 5 seasonal workers (see Figure 4, bottom right, $\mathrm{N}=138$ ).

\footnotetext{
${ }^{2}$ Denotes that respondents assign greater importance either to the former or to the latter. By randomizing the order of the answers, these effects can be excluded. See, for example: Murphy, Hofacker, and Mizerski (2006).

${ }^{3}$ Population: fruticulture: 31.9\%; floriculture: 25.5\%; vegetable farms: $17.6 \%$; tree nurseries: $9.8 \%$; and other: $15.1 \%$. See: Gurrath (2006).
} 


\subsection{Structure of the Respondents in the Sample}

Basically, any responsible manager of a horticultural company is both the initiator of and affected by change processes. Responses from experienced decision makers within the company are important for the quality of the results. For a complete picture of the relevant parties of change processes, other hierarchical levels should be surveyed too. This point represents a weakness of the present study.

\section{(insert Figure 5 here)}

Nine out of ten respondents act as the owner, chairman, managing director or plant manager. The remaining $10 \%$ consist of directors or senior department heads (1\%), project managers (1\%) and department heads (8\%, $N=119$, as shown in Figure 5, left). The length of service in the company, which was also collected, shows only a few participants (3\%) with short employment duration. Most of the answers are based on longstanding knowledge of their own organization. Almost $90 \%$ of the respondents have corporate experience of ten years and more (see Figure 5, right, $\mathrm{N}=128$ ). The participants in the study are therefore, with a score of almost 90\%, top decision makers with many years of experience.

\section{Results and Discussion}

\subsection{Causes and Backgrounds of Change Management}

In comparative studies across all the industries in Germany, change management occupied a leading position among the personnel issues of the present and future (Claßen and von Kyaw, 2007). The importance of change management in horticulture also becomes apparent in this study. At present, change management is a very important issue in 35\% of horticultural companies $(\mathrm{N}=114)$. Many participants in the study, while looking into the future (in 2020), increased their assessment by one level (e.g. from important to very important); barely a respondent anticipated an importance decrease. This result indicates that decision makers in horticultural companies see a high need for change in the future. For the future, $87 \%$ of the respondents expect a major role of change management and only $13 \%$ a less important or insignificant value $(\mathrm{N}=106)$. 


\subsection{1 "Megatrends" Behind the Change Initiatives}

Profound changes in society, economy and technology are becoming ever more hostile from the viewing angle. These "megatrends" are the driving force for future change programs and embedded change management measures. From the literature (see: Aronoff, 1998, Maas, 2015 and Rump and Walter, 2013), comparative studies (see: Claßen, et al. 2003, Claßen, et al. 2005, Claßen and von Kyaw, 2007, von Kyaw and Claßen, 2010 and Keicher, et al. 2012) and the trade press, 22 "mega-trends" were identified. This list is not complete. However, allocated by the study participants to the category "others," the trends and developments will conform to just two aspects: changed consumer behavior and progressive market liberalization. Therefore, the selection represents the most important of the coming developments. Up to five aspects could be selected in answer to the question "Which 5 'megatrends' will be the causes of fundamental change processes in your company in the next decade?" (see Figure 6).

\section{(insert Figure 6 here)}

The main theme environment (64\%) is considered to be the most important megatrend by far. This includes both the effects of climate change and the topics of environmental regulations and costs, which are especially relevant to horticulture. The subject area demographics, with 32\%, is the fifth most important megatrend in German production horticulture. In the comparative study on all industries across the German-speaking world, demographics, with $48 \%$ of the responses, was the most important megatrend. In second place, with $48 \%$, is the megatrend changing consumer behavior (such as rising health consciousness) in German production horticulture, followed by shortage of resources/prices (e.g. raw materials), with $40 \%$, and changes in the labor market ("war for talent" and shortage of skilled personnel).

Human resource issues can be found particularly frequently in the megatrends. They include megatrends such as the labor market, demographics, working attitude, urbanization, diversity, division of labor, working methods and women, for example their share in management positions. 
Other typical sustainability issues are among the megatrends in German horticulture and clearly top the list: environment, changing consumer behavior and resource shortages/prices. Thus, sustainability issues will be the megatrends of the next decade and will, from the perspective of decision makers, be the cause of fundamental change processes in German production horticulture companies. The progressive market liberalization and simultaneous concentration processes account for $22 \%$ of the 124 horticulture enterprises that count this issue as being among the most important change causes. The acceleration (e.g. "time to market," shorter product life cycles) is clearly noticeable for $16 \%$ of the respondents.

The other megatrends with a certain degree of importance ( $>10 \%)$ are hardly surprising. Each of these issues could be investigated in greater depth as a starting point for transformation processes: the Internet, for example Web 2.0 (facebook, etc.) and increasingly convergence media (smart TVs, phones), with 23\%, urbanization (e.g., metropolises, rural exodus), with 15\%, and new technologies (e.g., nano-, bio- and gene technology), with $11 \%$. Six of the megatrends play a negligible role for horticultural companies.

As shown in Figure 1, other structural factors were also examined. The results show a significant negative correlation with the number of seasonal workers and the importance of the megatrends demographics $\left(\tau_{\mathrm{b}}=-.25 ; \mathrm{p}<0.01 ; \mathrm{n}=138\right)$ and a positive correlation with the importance of financial markets $\left(\tau_{\mathrm{b}}=.20 ; \mathrm{p}<0.05 ; \mathrm{n}=138\right)$ as well as the end of nation states $\left(\tau_{\mathrm{b}}=.18 ; \mathrm{p}<0.05 ; \mathrm{n}=138\right)$.

The assessment of the surveyed decision makers with respect to the economic success of their own business compared with that of direct competitors is positively related to the importance of the topic labor market (e.g. "war for talent," shortage of skilled personnel; $\left.\tau_{b}=.20 ; \mathrm{p}<0.05 ; \mathrm{n}=114\right)$. For successful growth-oriented companies, the skilled labor shortage is already a resource bottleneck. This assessment is also reflected in the result that companies that have achieved their targets with respect to quantifiable indicators on average over the past two years consider the development on the labor market $\left(\tau_{\mathrm{b}}=.28 ; \mathrm{p}<0.01 ; \mathrm{n}=72\right)$ to be especially relevant.

For horticultural companies, for which dealing with change processes in the future is particularly important, the importance of the megatrends resource shortages/prices 
$\left(\tau_{\mathrm{b}}=.18 ; \mathrm{p}<0.05 ; \mathrm{n}=106\right)$ and progressive market liberalization and simultaneous concentration processes $\left(\tau_{b}=.25 ; \mathrm{p}<0.01 ; \mathrm{n}=106\right)$ is particularly high. This shows that horticultural companies that are "forced" by external developments to adapt to changes are more dependent on assistance with the implementation of change projects or expect stronger opposition within the company than companies that adjust proactively to changing environmental conditions.

A significant negative correlation is shown in the subjective level of difficulty in terms of the change taking place within the company and the importance of the trend IT flexibility $\left(\tau_{\mathrm{b}}=-.21 ; \mathrm{p}<0.05 ; \mathrm{n}=97\right)$ and a positive correlation with the importance of shortage of resources/prices $\left(\tau_{\mathrm{b}}=.21 ; \mathrm{p}<0.05 ; \mathrm{n}=97\right)$. This result could indicate that more technologically advanced horticultural companies estimate the level of difficulty of the current changes to be lower, because they are generally more open to innovations and/or have gathered more experience with different (technology-related) processes of change. For horticultural companies that are affected by a shortage of resources and corresponding prices, the current processes of change seem to be perceived as particularly difficult.

\subsubsection{Occasions of Change Projects in Horticultural Companies}

Change management is not an end in itself but the response to a need for change within the company. To be able to design suitable change management, the change's cause and requirements should be identified. These largely determine the appropriate transformation architecture. The participants in the study were asked to specify the most common causes of change projects in their companies in the next 3 years from a selection of 15 different examples.

(insert Figure 7 here)

As can be seen in Figure 7, five main reasons for change in horticultural companies can be identified.

- Changed market strategy/sales approach (42\%) - The customer as a dynamic creature requires the continuous attention of the company. Adjustments to changing demand structures and behaviors are the key to survival and the expected return on investment of the owners. 
- Corporate succession/business handover (40\%) - Almost 90\% of the respondents have belonged to their company for more than ten years. For many horticultural companies, the succession is unclear. Furthermore, it is a fundamental process of change, which is connected to a large number of, mainly personal, challenges, especially in family-run businesses.

- External changes, laws, etc. (36\%) - Horticultural companies are subject to strict regulation and monitoring, particularly in the environmental field. The organizational structure and the production methods and technologies are therefore highly dependent on the legislation. Changes in political demands and currents can therefore quickly have a direct impact on corporate practices.

- Changed HR concepts (32\%) - Demographic change, urbanization and the changed working attitude of the staff require the reaction of the company to attract and retain staff in the future.

- Cost reduction programs (32\%) - As long as there are companies in market economies, the search for further efficiency gains will remain a significant driver of change initiatives, whether they are reactive "in difficult times" or, which is considered to be more purposeful, proactive "in better times."

In the comparative study (Claßen and von Kyaw, 2007, p. 15), the main reasons identified for change projects in Germany were restructuring/reorganization (49\%), growth initiatives (38\%), changed corporate strategy (33\%), cost-cutting programs/"rightsizing" (32\%), changes in market strategy/sales approach (32\%) and mergers and acquisitions (21\%, N=122). Here, the larger organization size compared with German horticultural businesses becomes apparent. However, the restructuring/reorganization option must be considered critical at this point, since restructuring and reorganization can be understood as synonyms for a change process. In some cases, it can be argued that restructuring takes place for its own sake, carried out for example after a change of leadership, to break historically grown structures and fiefdoms.

\subsubsection{Main Objective of the Change Initiatives in German Production Horticul- ture}

In the occasions instigating change projects, a number of background causes often come to fruition. In every tenth company, this currently involves increasing growth $(13 \%$, 
$\mathrm{N}=104$ ). In the comparative study of all the sectors in Germany, with $44 \%$, this was the main objective of change initiatives. Cutting costs was mentioned as the main target by $16 \%$ of the respondents. In the comparative study, the equivalent figure was $29 \%$. Quality improvement, with 30\%, is located in the first place for German horticultural companies (14\% in the comparative study). Often, however, the project objectives quality and cost reduction are in contradiction. For German production horticulture, the issue of sustainability is essential, given that $24 \%$ of the respondents named practicing sustainability as the main objective of their corporate changes. This item was not captured in the comparative study. That the list used, consisting of six main targets, is sufficient was demonstrated by the fact that only $14 \%$ ticked something quite different.

\subsection{Attitude of the Decision Makers towards Change Management}

Leadership is a key organizational issue in horticultural enterprises (Unpublished study by the ZBG: Organization 2020). Nevertheless, it raises the question of how leadership should be designed. In the management literature, two oversubscribed leadership types are typically listed (transformational and transactional leadership; see: Krüger, 2012). Considering change initiatives, generally neither of these two extremes is right or wrong. Therefore, a situational leadership style should be chosen (Cf.: Claßen and von Kyaw, 2007, p. 19). Transferred to management styles, this results in two types of managers. In the transactional type (rather "tough guy"), the employee dimension has subordinate, mostly secondary importance as long as success can be seen. This can be compared with the transformational employee-oriented manager, who reflects on all the decisions in the light of the impact on the stakeholder employee.

In addition to the normative, in the wake of the social dimension of sustainability's substantially fundamental question of what is "right," it is interesting that both types occur in corporate practice. For this reason, it was asked in the study how the following points of view are distributed among managers and entrepreneurs:

- "If the suffering of the employees is just large enough they will adapt to the necessary changes."

- "We need to make the persons concerned become participants and actively support the process of change." 
As response categories, ten intervals (ten percentage levels) were predefined. The clusters in the distributions provide a tendency for the views.

In the results, it is clear that most horticultural entrepreneurs and managers disagree with the statement "increased distress." More than 30\% of the respondents agree with the statement at $0 \%(\mathrm{~N}=100)$. A different picture emerges for the statement "we must ensure that those affected become involved.” Most of the respondents agree with this statement at a level of more than $50 \%$. However, only about $20 \%$ of the respondents agree with the statement $100 \%(\mathrm{~N}=108)$. The result could indicate that the employee orientation is indeed strong, but the willingness of decision makers to let the employees participate in the decision-making process does not exist to the same extent. A limiting factor is that the agreement on this issue is still no direct reference to the actual behavior of executives. At this point, a socially desirable response behavior (Stocke, 2004) could distort the result, in that the statement that the persons concerned should be made participants will indeed produce agreement, but the real leadership behavior shows a different picture.

\subsection{Challenges and Success Factors in Change Processes}

One of the major contributions of this study is the identification and analysis of the importance of success factors in change processes in German production horticulture. On the basis of Senge (Senge, 1990) and Kotter (Kotter, 2011) but mainly grounded on the studies by Vahs (Vahs and Leiser, 2003) and Picot (Picot, et al. 1999), Schnitzler (unpublished) derived general factors of change success (see Figure 3) on the psychological level. These general factors of change success and their implementation in a practical process model (Meyerding, 2014a) form the basis for the analysis of the success factors in the present study. In the aforementioned process model, the factors are applied accordingly at different stages of the change project (Figure 2, above). The application and intensity of the factors must be designed individually and in detail for each change situation. The deduced factors of change success are confirmed by the studies of inter alia Claßen (Claßen, et al. 2005 and Claßen and von Kyaw, 2007) and Kyaw (von Kyaw and Claßen, 2010). 


\subsubsection{Challenges in the Implementation of Change Processes}

The first clue may be the respondents' indication of the success factors when asked about the obstacles to the implementation of corporate strategies and change processes. Essentially strategic confusion, political conflicts and technical mistakes were mentioned as reasons for difficulties encountered in implementation (see Figure 8). Too little willingness to take responsibility and interest conflicts and conflicts of objectives of the parties involved are each perceived by $34 \%$ of the respondents as the most difficult problems in the implementation of change processes. As a strategic problem, the surveyed decision makers in German horticultural production see that long-term measures are sacrificed for short-term improvements in earnings (29\%). In fourth place, with $25 \%$ of mentions, is the lack of skills/qualifications/expertise of those involved in the change process. Here a self-critical view of the horticulture entrepreneurs can be observed. Challenges that can be assigned to the factual level of the change process are in the middle of the most difficult challenges in the implementation of change initiatives. These are: no real sustainable monitoring/performance review of the activities (23\%), no clear objectives (22\%), too many activities without prioritizing (18\%) and weak project management (10\%). Change fatigue is clear for $12 \%$ of the respondents in the point paralysis of the organization through ongoing reorganization.

\section{(insert Figure 8 here)}

Other challenges were noted, with $8 \%$ of the respondents referring to the lack of an international/global perspective and the missing link between "top-down" and "bottomup" communication. Abandoning change management is considered as problematic only by $7 \%$ of the horticultural entrepreneurs. The lack of commitment of the owner has little relevance, with $5 \%$ of mentions. This result is, however, hardly surprising, since most of the participants are also the owner of the horticultural company under investigation. The challenges that result from a lack of concretization of the change by a business case and missing or lack of support from the line management, each accounting for 3\% of mentions, are relatively insignificant $(\mathrm{N}=77)$. Line management in the traditional sense, however, cannot be expected within the companies surveyed due to their size. 
In horticultural companies, which employ many seasonal workers, the challenge of the lack of clear objectives is perceived as less problematic $\left(\tau_{b}=-.16 ; p<0.05 ; n=138\right)$. For companies that consider themselves to be economically successful in relation to their direct competition, not enough change management $\left(\tau_{b}=-.20 ; \mathrm{p}<0.05 ; \mathrm{n}=114\right)$ is less of a problem. Other statistically significant relationships can be observed between the current importance of change management and the lack of support of line management $\left(\tau_{\mathrm{b}}=-.18 ; \mathrm{p}<0.05 ; \mathrm{n}=114\right)$, the paralysis of the organization through ongoing reorganization $\left(\tau_{\mathrm{b}}=.21, \mathrm{p}<0.05 ; \mathrm{n}=114\right)$ and the sacrifices of long-term measures for short-term improvements in earnings $\left(\tau_{\mathrm{b}}=.19 ; \mathrm{p}<0.05 ; \mathrm{n}=114\right)$. The results give the impression that the importance of change management is particularly recognized if deficits in strategic planning and implementation are visible. The same applies to the future importance of change management in the company and thus to the paralysis of the organization through ongoing reorganization $\left(\tau_{\mathrm{b}}=.20 ; \mathrm{p}<0.05\right.$; $\left.\mathrm{n}=106\right)$, no real sustainable monitoring/performance review of activities $\left(\tau_{\mathrm{b}}=.19 ; \mathrm{p}<0.05 ; \mathrm{n}=106\right)$ and the sacrifice of longterm measures for short-term improvements in earnings $\left(\tau_{\mathrm{b}}=.27 ; \mathrm{p}<0.01 ; \mathrm{n}=106\right)$. In addition, the perceived difficulty of the current change process within the company has a statistically significant relationship with some problem areas in the implementation of change processes (too many activities without prioritizing $\left(\tau_{\mathrm{b}}=.18 ; \mathrm{p}<0.05 ; \mathrm{n}=97\right.$ ), the paralysis of the organization through ongoing reorganization $\left(\tau_{b}=.20 ; p<0.05 ; n=97\right)$, waiver of change management $\left(\tau_{\mathrm{b}}=-.25 ; \mathrm{p}<0.01 ; \mathrm{n}=97\right)$ and the lack of commitment of the board/owner $\left.\left(\tau_{\mathrm{b}}=-.20 ; \mathrm{p}<0.05 ; \mathrm{n}=97\right)\right)$. Companies that could have achieved their goals very well on average over the past two years could also define clear objectives in the context of change projects $\left(\tau_{\mathrm{b}}=-.22 ; \mathrm{p}<0.05 ; \mathrm{n}=72\right)$. For companies with many employees, the problem of the missing link between "top-down" and "bottom-up" communication frequently appeared $\left(\tau_{\mathrm{b}}=.26 ; \mathrm{p}<0.01 ; \mathrm{n}=166\right)$.

\subsubsection{Success Factors in Change Processes}

In addition to the "negative" analysis - the question of the implementation barriers - the respondents were also asked about a "positive" view - the question of the success factors. The list of success factors demonstrates the high level of importance of soft factors in changes in German production horticulture, a conclusion that is slowly prevailing generally (Cf.: Todnem By, 2005). The broad diversification of the success factors indi- 
cates that there are not one or two factors of change success, but that only a sensible combination of success factors positively affects the result of change initiatives (see Figure 9; see Mento, Jones, and Dirndorfer, 2002).

(insert Figure 9 here)

At the top of the list of success factors that are known to the study participants from past change processes is a realistic, clear vision/goals and their communication, with $41 \%$. This shows that important foundations for the subsequent success of change are already set in the project phase of the strategic definition of goals. In addition, the team spirit and motivation of the project team or the change concerned were regarded as decisive for success (39\%). The timing factor (see Figures 3 and 9) accounts for $31 \%$ of the surveyed decision makers in German production horticulture concerning the three most important success factors. This is followed by the factors information/communication with the points open, clear communication within the project and towards others (26\%) and the "right" information policy (19\%). The leadership factor was mentioned fifth with the success factor "right" leadership (21\%). With $17 \%$ and $15 \%$, the success factors participation of those affected in the decision process and the training of the person concerned were named in places seven and nine. These two success factors are summarized in the factor participation and training. An understanding of the urgency of the need for change, therefore, is counted by $16 \%$ of the respondents among the main three factors for success. Other success factors reported, with $9 \%$, are the incentive system for those involved (factor incentives in Figure 3) and consistent monitoring and controlling of the change process (factor controlling). The commitment and the credibility of management are considered only by $7 \%$ of respondents to be among the three most important success factors. This result can be explained by the study participants themselves being the decision makers in the horticultural business. In the comparative study, this success factor was in first place, with $75 \%$. In the results of this question, the importance of the factors of the psychological level of the change project becomes apparent. Subjects of the factual level end up with projects/programs (5\%) and professional project management $(3 \%)$ in the rear seats of the success factors $(\mathrm{N}=98)$.

For companies with many employees, the commitment and credibility of management $\left(\tau_{\mathrm{b}}=.15 ; \mathrm{p}<0.05 ; \mathrm{n}=166\right)$ is more frequently counted among the three most important 
success factors, but a realistic, clear vision/goals and their communication $\left(\tau_{\mathrm{b}}=-.15\right.$; $\mathrm{p}<0.05 ; \mathrm{n}=166)$ and a tuned temporal approach $\left(\tau_{\mathrm{b}}=-.17 ; \mathrm{p}<0.05 ; \mathrm{n}=166\right)$ were rarely mentioned. Horticultural companies that see themselves as particularly economically successful compared with their direct competitors named the professional project management as having a significant impact on the success of change processes more often than less successful companies $\left(\tau_{b}=.18 ; \mathrm{p}<0.05 ; n=114\right)$. Surprisingly, companies that perceive the current change as being particularly difficult see professional project management as a success factor of transformation projects $\left(\tau_{b}=-.20 ; \mathrm{p}<0.05 ; \mathrm{n}=97\right)$ less frequently, even though these companies particularly frequently mentioned many activities without prioritizing $\left(\tau_{\mathrm{b}}=.18 ; \mathrm{p}<0.05 ; \mathrm{n}=97\right)$ and a paralysis of the organization through ongoing reorganization ( $\tau_{\mathrm{b}}=.20 ; \mathrm{p}<0.05$; $\mathrm{n}=97$ ), which actually just points to a lack of professional project management. Perhaps professional project management is not even recognized as a way to simplify the process of change.

Unlike the question in Figure 9, the respondents were then asked to look into their own companies (see Figure 10). Up to three success factors could be chosen. Again, the order for the respondents was randomized.

\section{(insert Figure 10 here)}

The results support the importance of the factors of the psychological level of the change process, so the involvement of employees in decision making (factor participation/training) is, with 53\% of the responses, in first place among the factors of successful change processes within the company. Decent leadership and acting as a role model (factor leadership behavior) can be found, with 47\%, in second place. In third place is the success factor reducing and avoiding conflicts and resistance (41\%). This success factor is not attributable to any of the general factors directly. Rather, the correct use of the factors (see Figure 3) is responsible for reducing and avoiding conflicts and resistance. Only as the fourth of the success factors does a topic from the factual level of change processes appear. The result of $31 \%$ of mentions of the point analyze and understand the situation and environment shows the importance of project phases one and two, strategic goal definition and analysis, to the success of change (see Figure 2). The development of the corporate culture is to be found in fifth place, with $25 \%$. The leadership factor (operationalized by the success factor correct leadership) occupies sixth 
place, with nearly 25\%. The factor information and communication reached seventh place, with $24 \%$. Further points that can be assigned to leadership behavior are identify and enshrine successes (19\%), promote leadership (12\%), force focus and alignment (3\%) and ensure mobilization and commitment (2\%). The factor incentives can be found in midfield with $17 \%$ of the mentions. The factors controlling, here operationalized as project/process controlling, with 10\%, and develop and build structure and monitoring, with $9 \%$, are located in the lower ranks. To carry out the training and development of target groups, the area of participation and training is of secondary importance (7\%) in German production horticulture. The same applies to the success factor of the factual level of the transformation process, capture and design organization and processes $(19 \%, \mathrm{~N}=93)$.

In companies with many employees (excluding seasonal workers), the right leadership behavior $\left(\tau_{\mathrm{b}}=.17 ; \mathrm{p}<0.05 ; \mathrm{n}=166\right)$ and the project/process controlling $\left(\tau_{\mathrm{b}}=.16 ; \mathrm{p}<0.05\right.$; $n=166$ ) were statistically significantly more frequently named as a success factor in the own business than in companies with fewer employees. With the increase in seasonal workers, the importance of the success factors reduce and prevent conflicts and resistance $\left(\tau_{\mathrm{b}}=-.17 ; \mathrm{p}<0.05 ; \mathrm{n}=138\right)$ and information and communication $\left(\tau_{\mathrm{b}}=-.23\right.$; $\mathrm{p}<0.05$; $\mathrm{n}=138$ ) decreases. Horticultural companies that perceive themselves to be economically successful compared with their competitors named the success factor training and development of target groups particularly more frequently in relation to the success of change processes in their companies $\left(\tau_{b}=.22 ; \mathrm{p}<0.05\right.$; $\left.=114\right)$.

\subsubsection{Structural Variables: Economic Success, "Difficulty" of Change and Change Speed}

As shown in Figure 1, in addition to the number of employees and the number of seasonal workers, more "structural variables" were collected, which can be assumed to have an influence on the various issues in the area of change management (for example, on the factors of success). One difficulty arises from the fact that these questions need to be answered especially subjectively. What is difficult? What is fast? The scale was also defined no further than the two extreme values of zero ("easy") and ten ("extremely difficult"). A limitation remains concerning the issue that no anchor was set. As already mentioned, the classifications represent the perceptions of the respondents and do not 
meet the criteria of reliability. However, they were a viable solution to analyze very different companies from different sectors of production horticulture and diverse change initiatives.

When asked about the difficulty of the changes currently taking place in the company on a scale from one (very easy) to ten (extremely difficult), an average degree of difficulty of 6.28 was observed $(\mathrm{N}=97)$. Figure 11 illustrates the results. They are particularly interesting with regard to the analysis of correlations with other issues.

(insert Figure 11 here)

Concerning the question "If you characterize the speed of your business - analogous to road traffic - how fast is your business moving," most decision makers in German production horticulture, considering the possible answers, described the speed of change as rather slow $(\mathrm{N}=34)$.

An average degree of target achievement of $66 \%$ was calculated from the answers to the question "to which extent were the goals achieved, on average, in the last two years?" (Figure 11, right). It appears that more than half (51\%) of all the change initiatives in German production horticulture can be viewed as a failure $(\mathrm{N}=72)$. Here, the need for enhanced change management competency becomes apparent.

The relationships between the collected structural variables are shown below. Companies with many employees (excluding seasonal workers) also deal with many seasonal workers (or vice versa) $\left(\mathrm{r}_{\mathrm{s}}=.27 ; \mathrm{p}<0.01 ; \mathrm{n}=136\right)$ and perceive a greater change speed $\left(\mathrm{r}_{\mathrm{s}}=.37 ; \mathrm{p}<0.05 ; \mathrm{n}=31\right)$. Relationships between the number of seasonal workers and the perceived economic success compared with direct competitors $\left(\mathrm{r}_{\mathrm{s}}=.30 ; \mathrm{p}<0.01 ; \mathrm{n}=93\right)$, the current importance of change management $\left(\mathrm{r}_{\mathrm{s}}=.23 ; \mathrm{p}<0.05 ; \mathrm{n}=92\right)$, the average achievement of quantitative indicators $\left(\mathrm{r}_{\mathrm{s}}=.30 ; \mathrm{p}<0.05 ; \mathrm{n}=60\right)$ and the perceived pace of change $\left(\mathrm{r}_{\mathrm{s}}=.43 ; \mathrm{p}<0.05 ; \mathrm{n}=28\right)$ can be observed. A considerable, significant relationship is apparent for the structural variables of economic success, particularly for the degree of target achievement, as measured by quantitative indicators $\left(\mathrm{r}_{\mathrm{s}}=.50 ; \mathrm{p}<0.01 ; \mathrm{n}=71\right)$ and the perceived pace of change $\left(\mathrm{r}_{\mathrm{s}}=.46 ; \mathrm{p}<0.01 ; \mathrm{n}=34\right)$. Decision makers who believe that change management will be particularly important in the future assess the difficulty 
of the change process taking place in their company as being particularly high (or vice versa; $\left.r_{s}=.23 ; p<0.05 ; n=86\right)$. Furthermore, there is a relationship between the average achievement of objectives based on quantifiable metrics in the past two years and the perceived pace of change $\left(\mathrm{r}_{\mathrm{s}}=.58 ; \mathrm{p}<0.01 ; \mathrm{n}=27\right)$. It could be concluded that successful companies are changing faster than less successful ones. However, the relationships shown illustrate mainly the consistency and traceability of the response behavior.

\section{Conclusion}

The German production horticulture sector has been experiencing a structural shift towards larger organizational units for decades. As shown in the development models of companies, for example those presented by Greiner (1983) and Bleicher (1991), this growth of organizations is already leading to potential crises, which have to be overcome in change initiatives. Furthermore, the corporate environment is changing increasingly. The study has identified the main megatrends, which will be the cause of the fundamental change processes in German production horticulture companies over the next decade. These are mainly trends regarding the environment, modified consumer behavior, resource shortages and the labor market. The horticultural entrepreneurs see the main objectives of change projects as the improvement of product quality and sustainable agricultural practices; only afterwards should the costs be reduced. In the next three years, changing market strategies, customer approaches and corporate succession/business handover, as well as external changes, for example the legal situation, will be the most common causes of changes in the horticultural companies studied. The study also points out that the importance of dealing with processes of change is detected by the horticultural entrepreneurs and will increase even further in the future.

Change management involves a factual level and a psychological level. The two levels need to be developed simultaneously to avoid a reality gap between the structural change and the behavioral change of those involved. The horticultural entrepreneurs surveyed recognize the need to involve those who are affected, for example in the decision-making process. Overall, the study demonstrates that dealing with change processes has little professional design in most horticultural companies. German production horticulture is faced with the challenge of improving its ability to transform significantly. Therefore, business consultancy services can make a valuable contribution. 
The study indicates that the most difficult problems encountered in the implementation of change processes arise especially from low willingness to take responsibility and interest and goal conflicts of those involved. In addition, long-term measures are often sacrificed for short-term improvements in results. The study also provides important clues to which success factors are crucial to the success of change initiatives. Mentioned here are in particular a realistic, clear vision and goals as well as their communication within the company. In second place, the importance of the psychological level of change management becomes apparent through the point team spirit and motivation. Furthermore, the relevance of a coordinated temporal approach to the change success is shown in the study.

From the comparative studies and the results of the present study, six factors of the psychological level of change management can be derived. These are leadership behavior, controlling, incentives, participation and training, information and communication and timing. The use and configuration of these factors in the various stages of a change project are, as the present study shows, dependent on the organizational structure, which includes the number of employees and the number of seasonal workers, as well as on the economic success of the company, the difficulty of the change and the pace of change. In the surveyed horticultural companies, the factors participation and training (with the aspect of engaging employees in decision making) and leadership behavior (with the aspect of adequate leadership, acting as a role model) were particularly frequently identified as being crucial to the success of change.

Economically sustainable horticultural companies are able, as far as possible proactively, to adapt to changing environmental conditions. Not only the classical indicators of profitability, stability and liquidity help to reflect adequately the economic dimension of sustainability. The ability to change may therefore represent a key indicator of the economic sustainability of horticultural companies. The identified success factors in this study could be levied for this purpose in a questionnaire and compared with the average of the respective sector.

Due to the small number of cases, for example regarding the loss of productivity and turnover rate, the influences of the success factors could not be quantified. Therefore, 
further research is needed to determine the relative influence of different factors on the success of change. However, such measurements are complex, because not only the implementation of certain measures but also their timing and interdependencies are expected to affect the success of change. A sensible supplement to the present study would also be a survey of employees and external consultants concerning the success factors of change initiatives in German horticulture, as this would be likely to lead to different results.

\section{References}

Aronoff, C. E. (1998). Megatrends in Family Business. Family Business Review, 11(3), 181-186. doi:10.1111/j.1741-6248.1998.00181.x

Berndt, M. (1984). Ein theoretischer Bezugsrahmen für die Planung der Entwicklung von Gartenbaubetrieben (Dissertation). Universität Hannover, Hannover.

Bleicher, K. (1991). Organisation: Strategien, Strukturen, Kulturen (2nd ed.). Wiesbaden: Gabler.

Bock, C. (1994). Der Gartenbau in den neuen Bundesländern im Transformationsprozeß in die Marktwirtschaft (Dissertation). Universität Hannover, Hannover.

Böckelmann, S. (1992). Unternehmertypus und Organisationsstruktur (Dissertation). Universität Hannover, Hannover.

Claßen, M. \& Kyaw, F. von. (2007). Change Management-Studie 2008: Business Transformation - Veränderungen erfolgreich gestalten. Berlin.

Claßen, M., Alex, B., \& Arnold, S. (2003). Change Management 2003 (Studien Brochüre). Berlin.

Claßen, M., Arnold, S., \& Papritz, N. (2005). Veränderungen erfolgreich gestalten Change Management 2005: Bedeutung, Strategien, Trends (Studien Brochüre). Berlin.

Field, A. P. (2009). Discovering statistics using SPSS: (and sex and drugs and rock ' $n$ ' roll) (3rd ed.). Introducing statistical methods. Los Angeles [i.e. Thousand Oaks, Calif.], London: Sage Publications.

Gattermeyer, W. (2001). Change-Management und Unternehmenserfolg: Grundlagen Methoden - Praxisbeispiele (2nd ed.). Wiesbaden: Gabler. 
Greiner, L. E. (1983). Evolution und Revolution im Wachstum von Organisationen.

Harvard-Manager : Periodikum zu Theorie u. Praxis d. Managements, (3), 7-15.

Gurrath, P. (2006). Ergebnisse der Gartenbauerhebung 2005 (Wirtschaft und Statistik No. 10/2006). Wiesbaden.

Haymarket Media. (2009). TASPO Gartenbau- Adressbuch Süd. Braunschweig: Haymarket Media.

Haymarket Media. (2010). TASPO Gartenbau- Adressbuch Nord. Braunschweig: Haymarket Media.

Keicher, I., Anke, T., Bohn, U., Crummenerl, C., \& Mergenthal, N. (2012). Digitale Revolution: Ist Change Management mutig genug für die Zukunft? (Studien Brochüre). Berlin.

Kettinger, W. J., \& Grover, V. (1995). Special Section: Toward a Theory of Business Process Change Management. Journal of Management Information Systems, 12(1), 9-30. doi:10.2307/40398151

Klaffke, M. (2005). Mitarbeiter für den Wandel begeistern. Personalführung, (12), 5463.

Kotter, J. P. (2011). Leading Change: Wie Sie Ihr Unternehmen in acht Schritten erfolgreich verändern (1st ed.). München: Vahlen, Franz.

Krüger, W. (2012). Führungsstile für erfolgreichen Wandel. In H. Bruch, S. Krummacher, \& B. Vogel (Eds.), Leadership - Best Practices und Trends (2nd ed., pp. 99114). Wiesbaden: Gabler.

Kyaw, F. von \& Claßen, M. (2010). Change Management Studie 2010: Business Transformation - Veränderungen erfolgreich gestalten.

Lewin, K. (1953). Die Lösung sozialer Konflikte: Ausgewählte Abhandlungen über Gruppendynamik. (Weiss Lewin, G., Ed.). Bad Nauheim: Christian-Verl.

Maas, P. (2015). 2050 Megatrends, Alltagswelten, Zukunftsmärkte. St. Gallen: Univ. St. Gallen.

Mento, A., Jones, R., \& Dirndorfer, W. (2002). A change management process: Grounded in both theory and practice. Journal of Change Management, 3(1), 45-59. doi:10.1080/714042520

Meyerding, S. (2014a). Change-Management als neue Herausforderung für den deutschen Gartenbau - "Stellschrauben" des Veränderungserfolgs und praxisorientiertes 
Vorgehensmodell. In Zentrum für Betriebswirtschaft im Gartenbau e. V. (Ed.), Zusammenfassung der 52. Betriebswirtschaftlichen Fachtagung Gartenbau, Geschäftsmodelle, Controlling und Kennzahlen vom 15. bis 18. September 2014 in Erfurt (pp. 130-142). Hannover,

Meyerding, S. (2014b). Exposé: Change Management Studie 2015. In Zentrum für Betriebswirtschaft im Gartenbau e. V. (Ed.), Zusammenfassung der 52. Betriebswirtschaftlichen Fachtagung Gartenbau, Geschäftsmodelle, Controlling und Kennzahlen vom 15. bis 18. September 2014 in Erfurt (pp. 125-129). Hannover,

Murphy, J., Hofacker, C., \& Mizerski, R. (2006). Primacy and Recency Effects on Clicking Behavior. Journal of Computer-Mediated Communication, 11(2), 522-535. doi:10.1111/j.1083-6101.2006.00025.x

Picot, A., Freudenberg, H., \& Gaßner, W. (1999). Management von Reorganisationen: Massschneidern als Konzept für den Wandel. Wiesbaden: Gabler.

Rump, J., \& Walter, N. (2013). Arbeitswelt 2030: Trends, Prognosen, Gestaltungsmöglichkeiten. Stuttgart: Schäffer-Poeschel. Retrieved from http://site.ebrary.com/lib/subhamburg/Doc?id=10746613

Senge, P. M. (1990). The fifth discipline: The art and practice of the learning organization. A currency book. New York: Doubleday.

Stocke, V. (2004). Entstehungsbedingungen von Antwortverzerrungen durch soziale Erwunschtheit. Ein Vergleich der Prognosen der Rational-Choice Theorie und de Modells der Frame-Selektion. Zeitschrift für Soziologie, 33(4), 303-320.

Storck, H., \& Bokelmann, W. (1995). Grundzüge der gartenbaulichen Betriebslehre: 17 Tabellen. Stuttgart: Ulmer.

Todnem By, R. (2005). Organisational change management: A critical review. Journal of Change Management, 5(4), 369-380. doi:10.1080/14697010500359250

Tran, Q., \& Tian, Y. (2013). Organizational Structure: Influencing Factors and Impact on a Firm. American Journal of Industrial and Business Management, 3, 229-236. doi: 10.4236/ajibm.2013.32028

Vahs, D. (2007). Organisation: Einführung in die Organisationstheorie und -praxis (6th ed.). Stuttgart: Schäffer-Poeschel.

Vahs, D., \& Leiser, W. (2003). Change Management in schwierigen Zeiten: Erfolgsfaktoren und Handlungsempfehlungen für die Gestaltung von Veränderungsprozessen (1st ed.). Wirtschaftswissenschaft. Wiesbaden: Dt. Univ.-Verl. 
Walker, J. H., Armenakis, A. A., \& Bernerth, J. B. (2007). Factors influencing organizational change efforts. Journal of Organizational Change Management, 20(6), 761773. doi:10.1108/09534810710831000

\section{Figures}

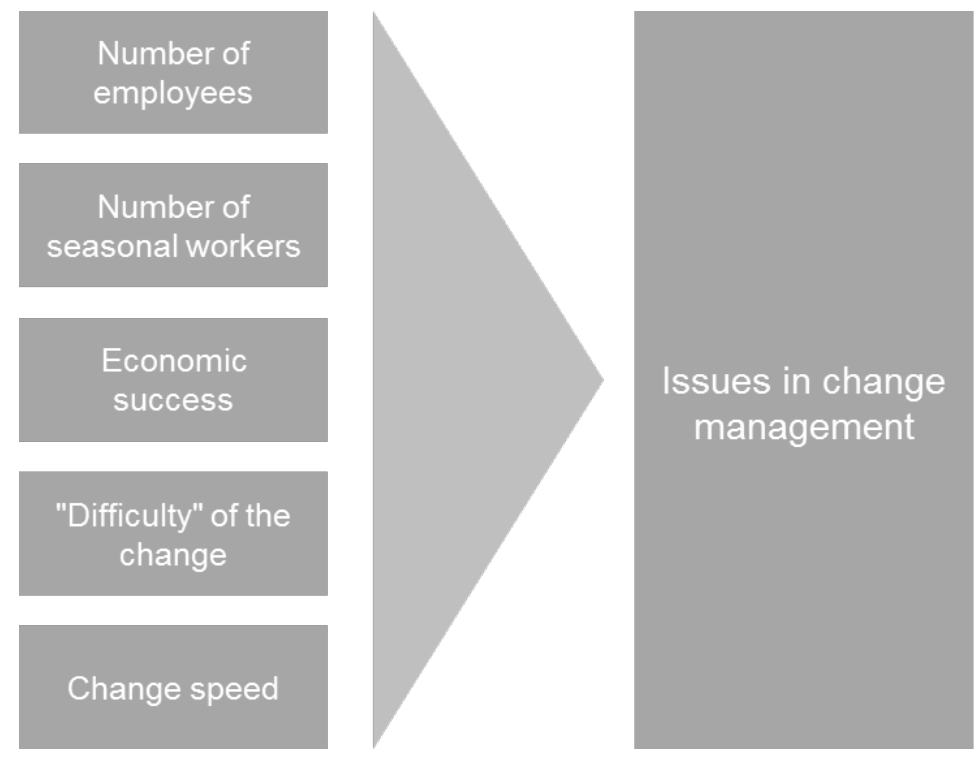

Figure 1: Investigated factors influencing thematic areas of change management (own illustration: Cf.: Kettinger and Grover, 1995 and Walker et al., 2007)
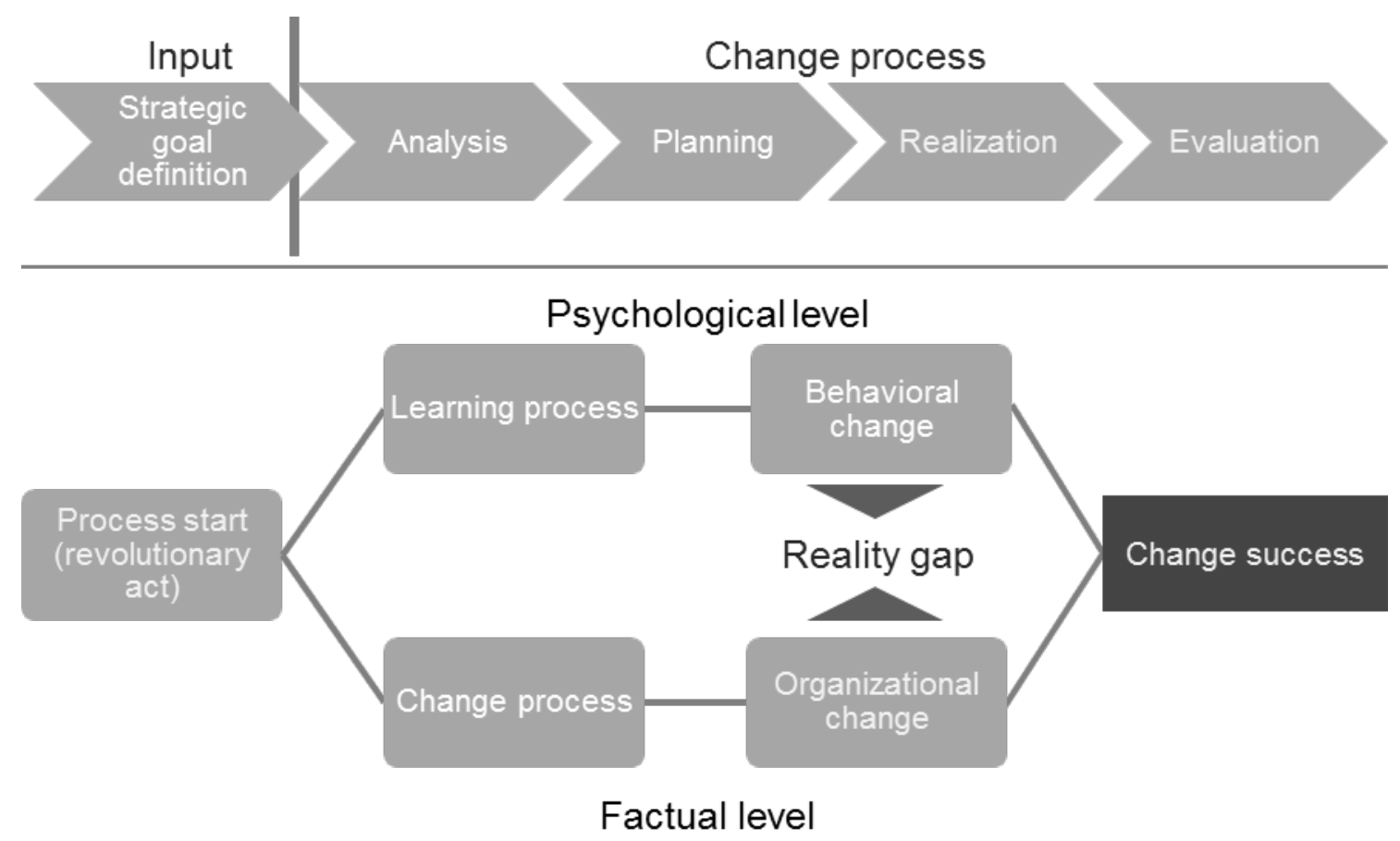

Figure 2: Methodology to avoid the reality gap (own illustration: Cf.: Vahs, 2007, p. 392) 


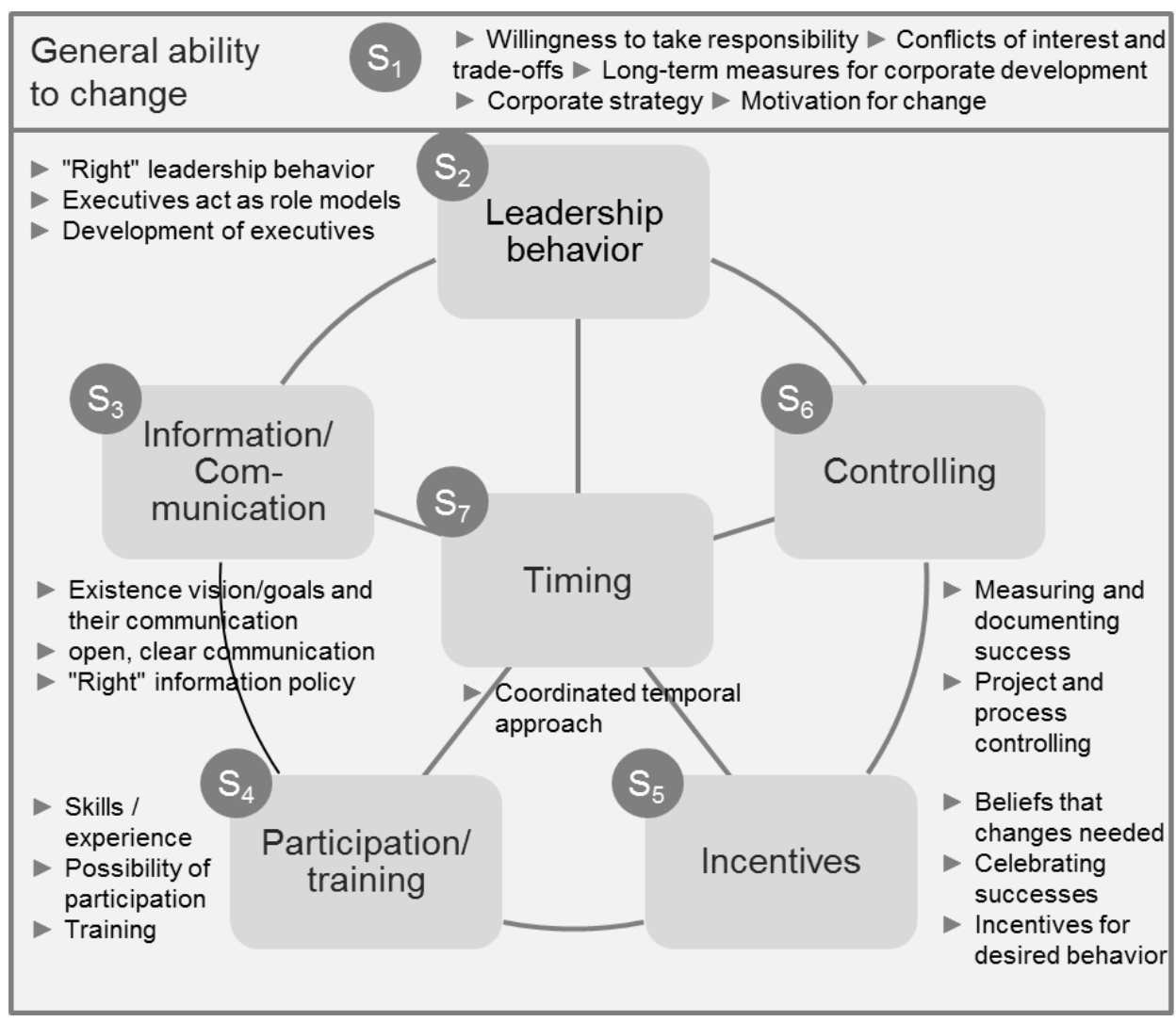

Figure 3: Assignment of questions to the success factors of change at the psychological level

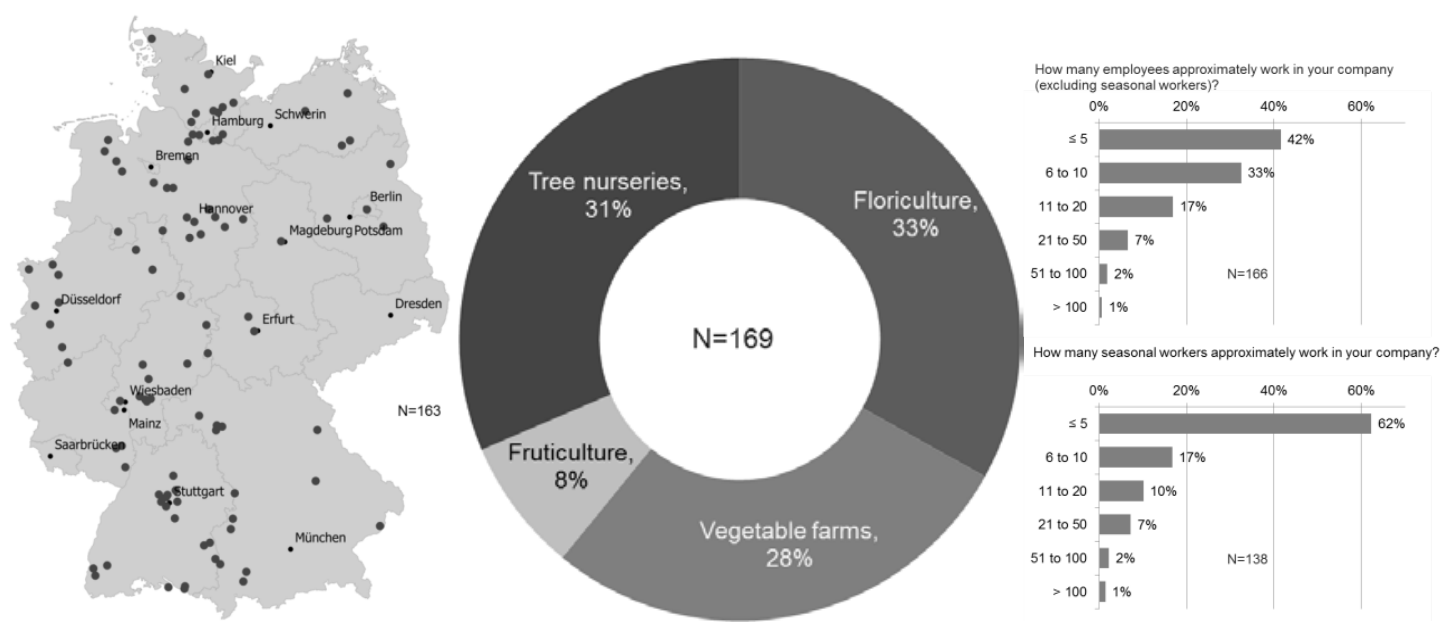

Figure 4: Structure of the companies in the sample 
What is your position in the company?

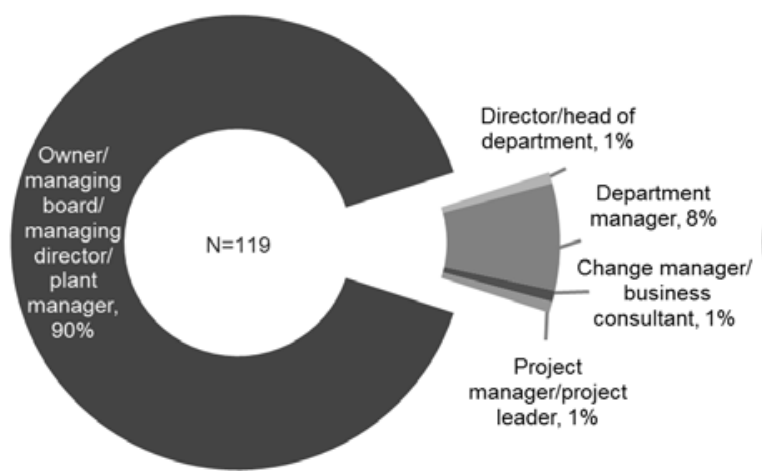

How long have you belonged to the company?

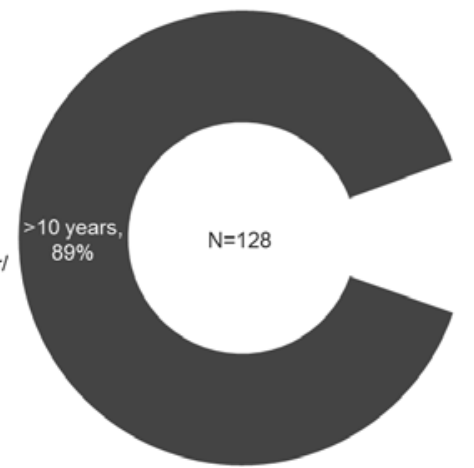

1 to 3 years, $3 \%$

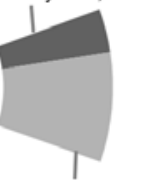

3 to 10 years, $8 \%$

Figure 5: Structure of the respondents in the sample

Which 5 "megatrends" will be the causes of fundamental change processes in your company in the next decade? (Multiple choice)

Environment, e.g. climate change, requirements, costs Changed consumer behavior, e.g. rising health awareness Resource shortages/prices, e.g. raw materials Labor market, e.g. "war for talents," shortage of skilled workers Demography, e.g. age pyramid Internet, e.g. Web 2.0 (facebook), convergence media (smart TV, phone) Ongoing market deregulation with simultaneous concentration processes Work attitude, e.g. "work-life balance" Acceleration, e.g. "time to market," shorter product life cycles

Urbanization, e.g. metropolises, rural exodus New technologies, e.g. nano-, bio-, gene technology Global sourcing, e.g. worldwide procurement Complexity, e.g. end of uniqueness

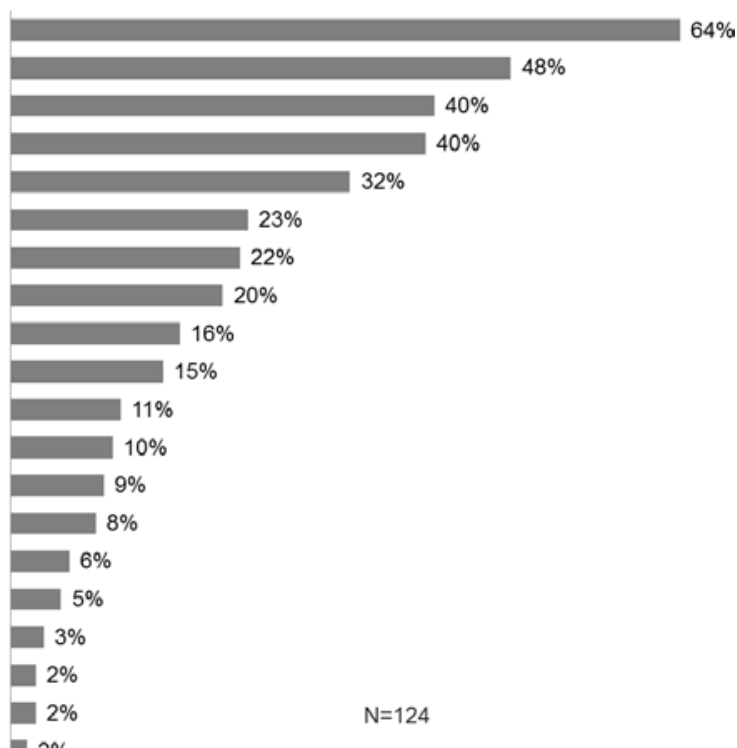

Diversity, e.g. share of people with a migration background
Asia, e.g. China, India Division of labor, e.g. focused value creation Forms of work, e.g. home office, virtual organizations $\square 3 \%$ End of nation states, e.g. regional alliances $\quad 2 \%$

Financial markets, e.g. regional alliances $\square 2 \%$

Women, e.g. shares in leading positions $2 \%$

Corporate governance, e.g. shareholder focus $2 \%$

IT flexibility, e.g. service-oriented architecture (SOA) $\quad 2 \%$

\section{Figure 6: "Megatrends" in German production horticulture}


Which will be the most common causes of changes in your company in the next 3 years? (Multiple answers possible)

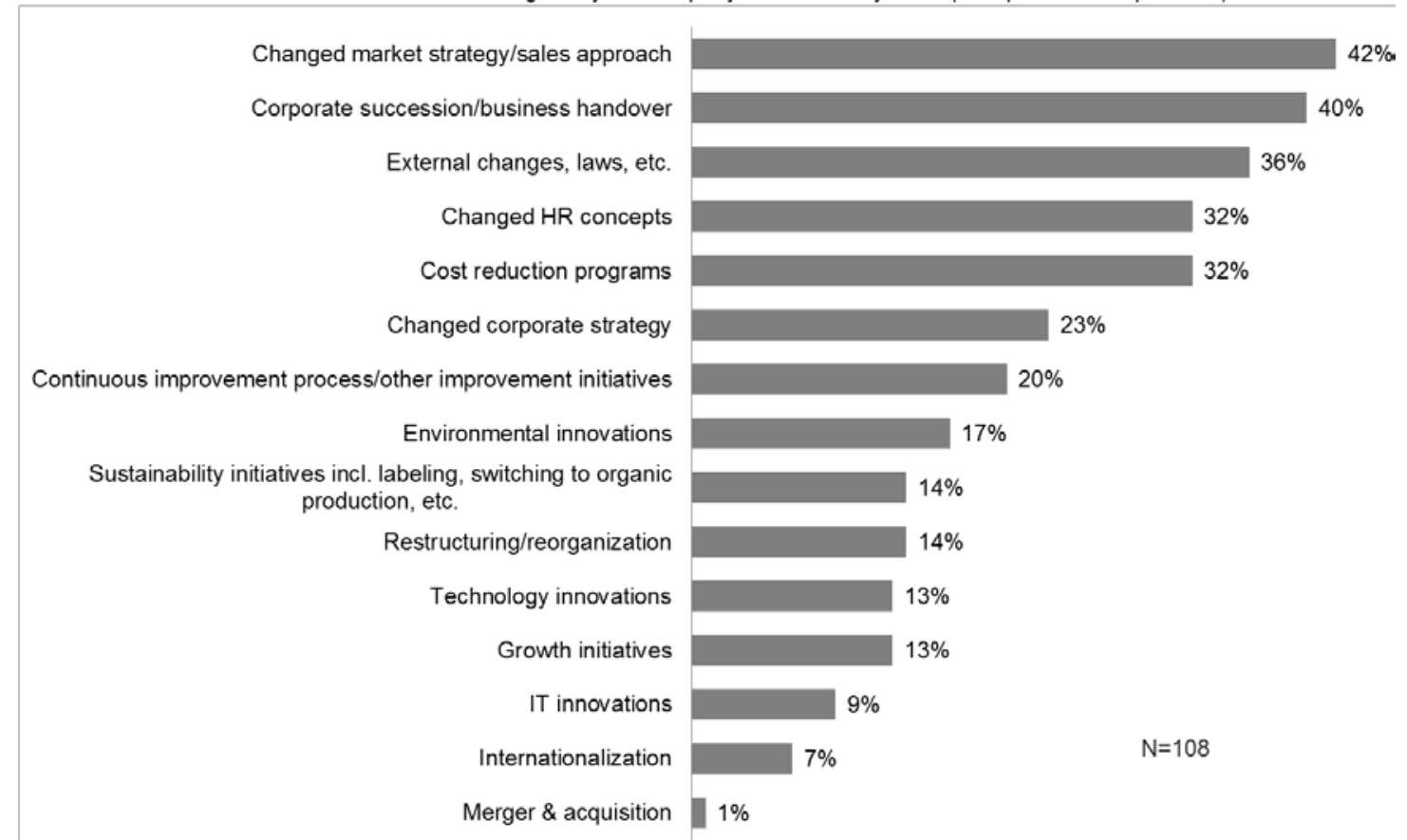

Figure 7: Causes of change projects in the next three years

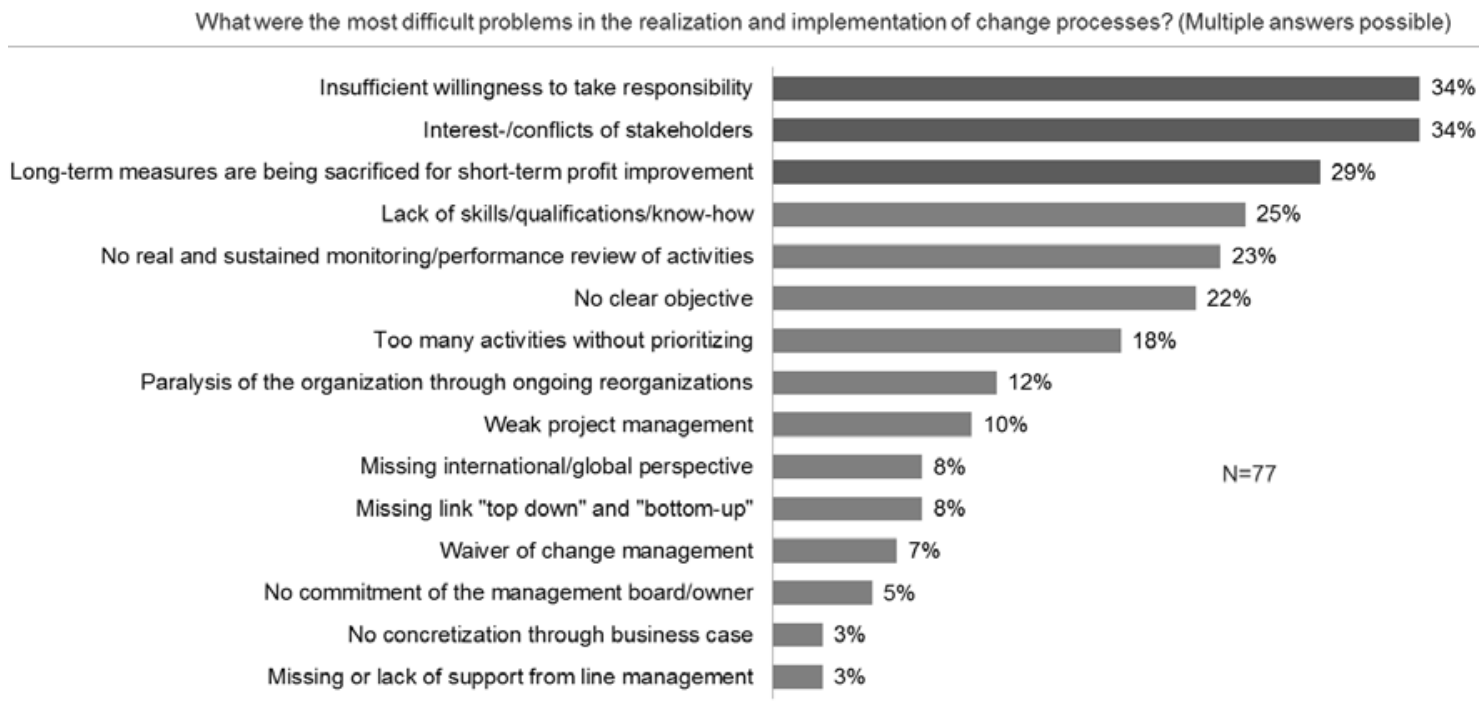

Figure 8: Problems in change processes 
Realistic, clear vision/goals and their communication

Team spirit and motivation ("winning spirit")

A coordinated temporal approach, timing

Open, clear communication within the project and towards others

"Right" leadership

"Right" information policy

Participation of stakeholders in decision-making

Sense of urgency

Training of those affected

Incentive system for those involved

Systematic monitoring and controlling of the process

Commitment and management credibility

Project/programs
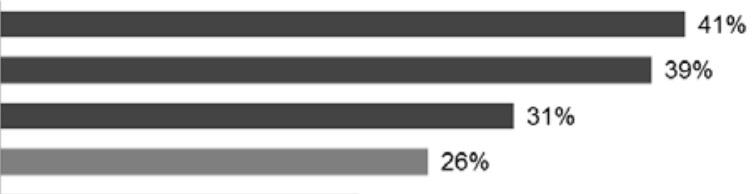

$26 \%$

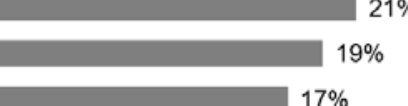

\section{$\%$}
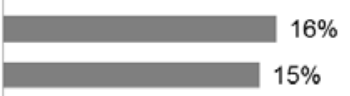

$9 \%$

$8 \%$

$7 \%$

$5 \%$

$\mathrm{N}=98$

Professional project management $\quad 3 \%$

Effective stakeholder management $\quad 2 \%$

\section{Figure 9: Success factors in known change processes}

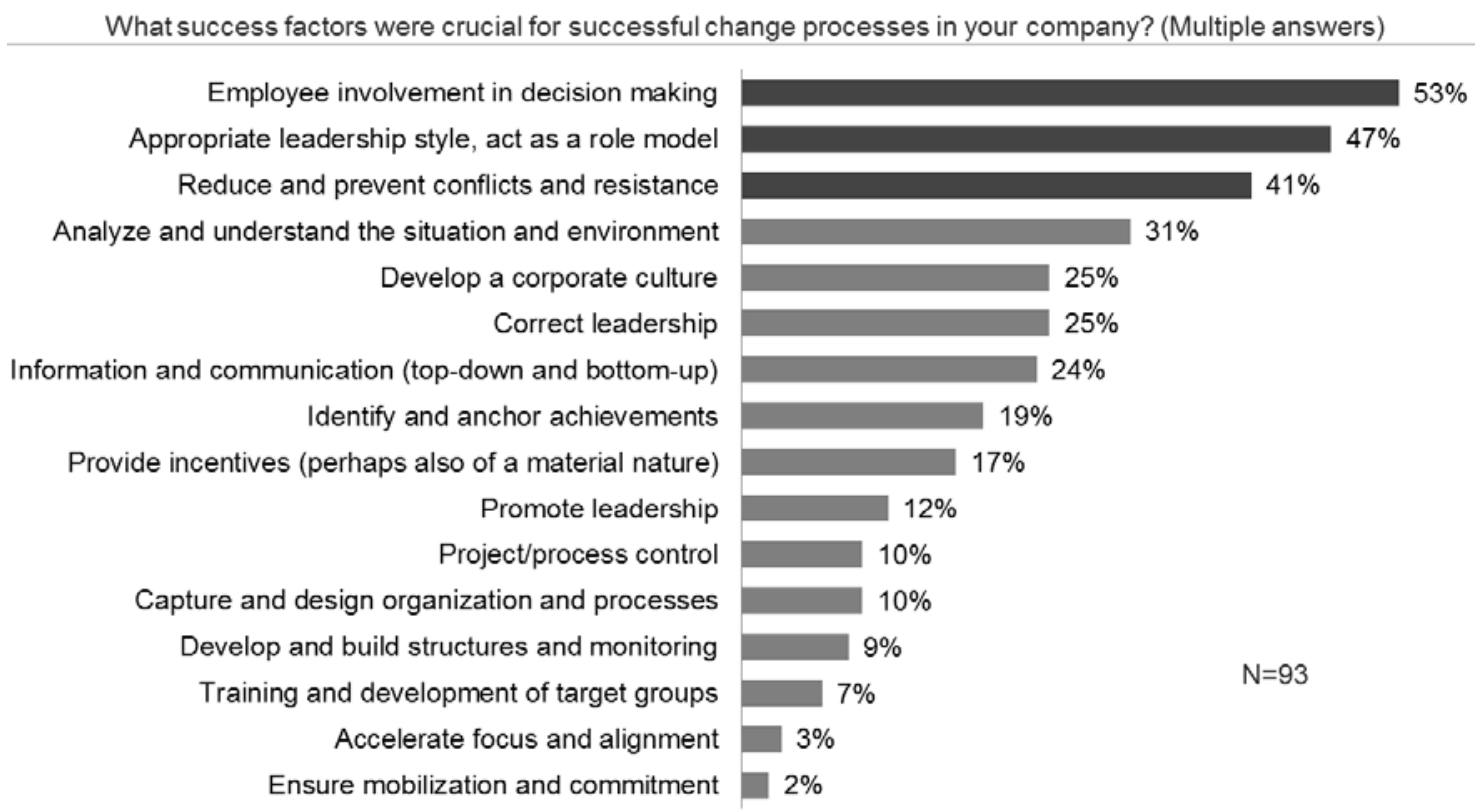

Figure 10: Success factors in change processes within the company

What "difficulty" do you currently see in terms of the ongoing changes in your company?

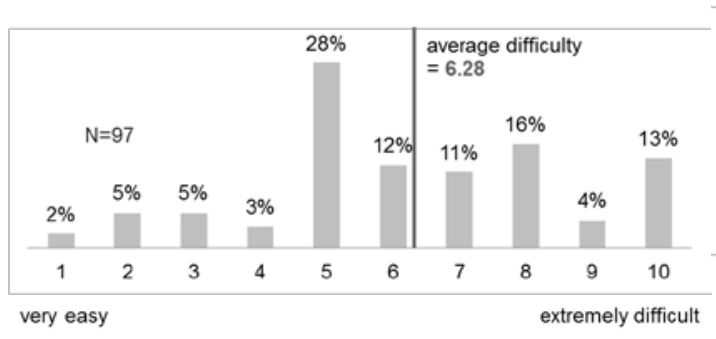

To which extent were the goals achieved, on average, in the last two years?

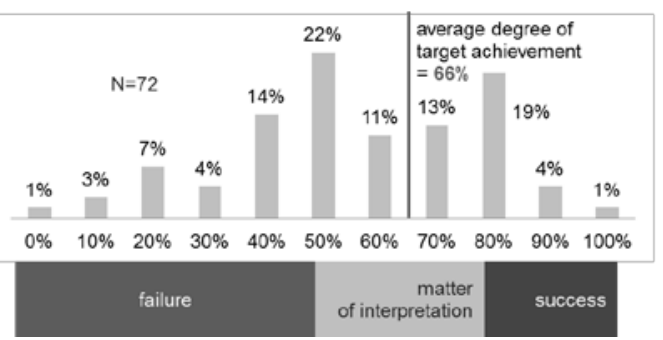

Figure 11: Degree of difficulty (left) and degree of target achievement (right) of change initiatives over the past two years 